\title{
A set of 17 single nucleotide polymorphism (SNP) markers for European beech (Fagus sylvatica $\mathbf{L}$.)
}

\author{
S. Seifert • B. Vornam • R. Finkeldey
}

Received: 19 June 2012/ Accepted: 25 June 2012

(C) The Author(s) 2012. This article is published with open access at Springerlink.com

\begin{abstract}
In view of the predicted changing environmental conditions, the question arises whether the important tree species European beech (Fagus sylvatica L.) will be adaptable to the future climate in Europe. Only few studies investigated the genetic background of drought stress tolerance in beech. In this study a set of 17 SNP (Single Nucleotide Polymorphism) markers selected from eight candidate genes potentially involved in drought stress response were developed. The polymorphisms of these markers were analysed in 50 adult trees from a population in Germany by using two multiplex sets (SNaPshot ${ }^{\circledR}$ Multiplex Kit (Applied Biosystems)). Observed and expected heterozygosity ranged from 0.060 to 0.520 and from 0.059 to 0.505 , respectively. None of the loci showed a significant deviation from Hardy-Weinberg equilibrium.
\end{abstract}

Keywords Candidate gene - Drought stress ·

Climate change $\cdot$ SNP analysis $\cdot$ Adaptation

The forest tree species European beech (Fagus sylvatica) is one of the most important deciduous trees in Europe. The adaptation potential of beech to future environmental conditions is critically discussed in view of the predicted climate change (e.g., Ammer et al. 2005; Rennenberg et al. 2004). All climate change scenarios predict a warming for Europe during the next decades (EEA 2008; IPCC 2007). The overall precipitation is expected to change less, at least in the centre of the distribution of beech. However, less

S. Seifert $(\bowtie) \cdot$ B. Vornam $\cdot$ R. Finkeldey Faculty of Forest Sciences and Forest Ecology, Büsgen Institute, Forest Genetics and Forest Tree Breeding, Georg-AugustUniversity Göttingen, Büsgenweg 2, 37077 Göttingen, Germany e-mail: sseifer@gwdg.de precipitation is forecasted for the summer months (EEA 2008; IPCC 2007). Thus, beech is expected to experience increasing drought stress in summer. The consequences of these changes for beech populations are largely unknown (e.g., Geßler et al. 2007).

The identification of candidate genes related to drought stress tolerance and the analysis of the variation within these genes is a first step to better understand the genetic basis for this trait. Single nucleotide polymorphisms (SNPs) are the most frequent type of variation found in DNA (Brookes 1999) and are valuable markers to study genetic variation and the genetic basis for adaptation of tree species (e.g., Gailing et al. 2009; Ingvarsson et al. 2008). We developed a set of 17 SNP markers for beech derived from eight different candidate genes which are putatively involved in drought stress tolerance.

The search for candidate genes was literature based (Seifert et al. 2012). After successful primer design for parts of the candidate genes, 18 different trees from six different populations were sequenced in order to analyse the variation within these genes (as described in Seifert et al. 2012). In order to avoid potential sequencing errors, only variation appearing in at least two different trees was identified as a potential SNP. In total, 17 SNPs in coding and non-coding regions of the genes (Table 1) were selected. Primers were designed according to the SNaPshot $^{\circledR}$ Multiplex Kit (Applied Biosystems) by addition of nonhomologous polynucleotides (poly (dT)) of different lengths (Table 1) allowing the analysis of all SNPs in two multiplex reactions (Table 1). Primers were checked for self-annealing, dimer and hairpin formations using the program Oligo calc: Oligonucleotide Properties Calculator.

The SNPs were genotyped in one population in Northern Germany (N52 49.831 E10 18.985) comprising 50 individuals. Total DNA was extracted from leaves using the 


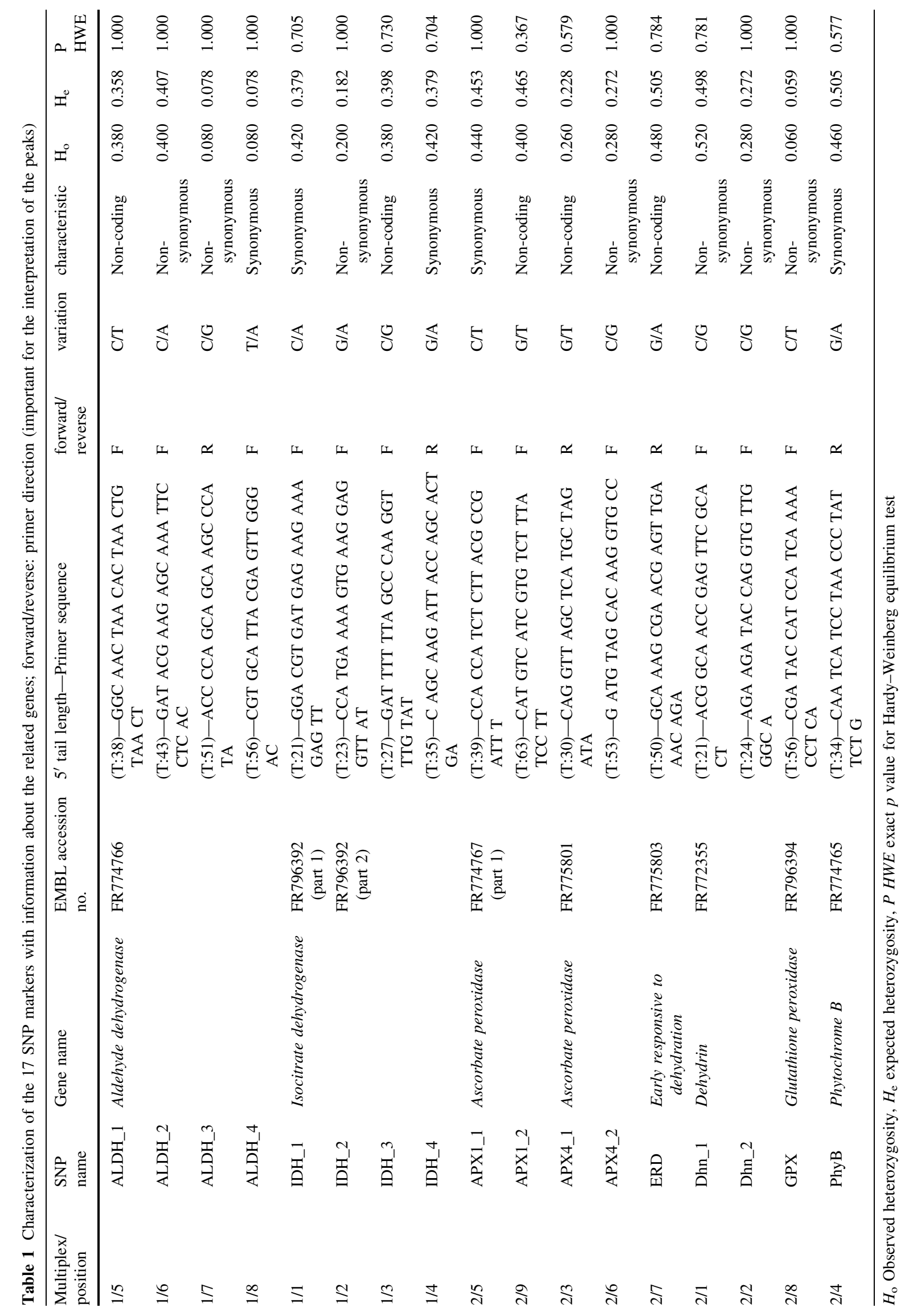


DNeasy $^{\mathrm{TM}} 96$ Plant Kit (Qiagen, Hilden, Germany). The candidate gene fragments were amplified as described in Seifert et al. (2012). After amplification of the genes, the PCR products were cleaned using 1 unit Exonuclease I (Affymetrix, Santa Clara, USA) and 2.5 units SAP (Shrimp Alkaline Phosphatase; Affymetrix, Santa Clara, USA), $37{ }^{\circ} \mathrm{C}$ for one hour and $75{ }^{\circ} \mathrm{C}$ for $15 \mathrm{~min}$.

SNaPshot ${ }^{\circledR}$ Multiplex Kit (Applied Biosystems) PCR amplifications were conducted in a $10 \mu \mathrm{l}$ volume containing $5 \mu \mathrm{l}$ of cleaned PCR product from the different genes, $5 \mu$ Reaction Mix (SNaPshot ${ }^{\circledR}$ Multiplex Kit (Applied Biosystems)) and $0.2 \mu \mathrm{M}$ of each primer. The PCR protocol consisted of 25 cycles of $96^{\circ} \mathrm{C}$ for $10 \mathrm{~s}$ (denaturation), $50{ }^{\circ} \mathrm{C}$ for $5 \mathrm{~s}$ (annealing), and $60{ }^{\circ} \mathrm{C}$ for $30 \mathrm{~s}$ (extension). The PCR products were again cleaned using 1 unit SAP (Affymetrix, Santa Clara, USA). Preparations for the SNP analysis were done according to the protocol. SNP analyses were performed on an ABI PRISM ${ }^{\circledR}$ 3100xl Genetic Analyzer (Applied Biosystems) and scored according to the protocol. No automatic scoring was used.

All SNPs showed bi-allelic polymorphisms. The observed $\left(\mathrm{H}_{\mathrm{o}}\right)$ and the expected $\left(\mathrm{H}_{\mathrm{e}}\right)$ heterozygosities and fixation index (F) were calculated using Arlequin 3.11 (Excoffier et al. 2007) and GenAlEx 6.3 (Peakall and Smouse 2006). Deviation from Hardy-Weinberg equilibrium was tested locuswise using 100,000 steps in Markov chain and 1,000 dememorization steps with Arlequin 3.11 (Excoffier et al. 2007). Linkage disequilibrium was tested using 10,000 dememorization steps, 100 batches and 5,000 iterations per batch with GENEPOP 4.0.11 (Rousset 2008).

For the 17 SNP loci, the observed heterozygosity $\left(\mathrm{H}_{\mathrm{o}}\right)$ varied from 0.06 to 0.52 with a mean of 0.326 , while the expected heterozygosity $\left(\mathrm{H}_{\mathrm{e}}\right)$ ranged from 0.059 to 0.505 with a mean of 0.324 (Table 1). No significant deviation from Hardy-Weinberg equilibrium was found. Significant linkage disequilibrium $(p<5 \%)$ was detected for 14 SNP pairs $(p<1 \%=$ seven pairs $)$, six $(p<1 \%=$ one pair $)$ of them between fragments from different genes.

The markers described here are useful genomic tools to investigate drought stress tolerance of $F$. sylvatica in natural populations or in controlled drought stress experiments.

Acknowledgments The study was supported by the Ministry for Science and Culture of Lower Saxony within the network KLIFFclimate impact and adaptation research in Lower Saxony. We thank A. Dolynska, G. Dinkel and A. Capelle for their technical help and all persons who assisted us doing field work. Furthermore, we want to thank K. Prinz and A. Vidalis for valuable comments and discussions.

Open Access This article is distributed under the terms of the Creative Commons Attribution License which permits any use, distribution, and reproduction in any medium, provided the original author(s) and the source are credited.

\section{References}

Ammer C, Albrecht L, Borchert H, Brosinger F, Dittmar C, Elling W, Ewald J, Felbermeier B, von Gilsa H, Huss J, Kenk G, Kölling C, Kohnle U, Meyer P, Mosandl R, Moosmayer HU, Palmer S, Reif A, Rehfuess KE, Stimm B (2005) Future suitability of beech (Fagus sylvatica L.) in Central Europe: critical remarks concerning a paper of Rennenberg et al. (2004). All Forst-u J-Ztg 176:60-67

Brookes A (1999) The essence of SNPs. Gene 234:177-186

EEA-European Environmental Agency (2008) Impacts of Europe's changing climate-2008 indicator-based assessment. Joint EEAJRC-WHO report. http://www.eea.europa.eu

Excoffier L, Laval G, Schneider S (2007) Arlequin (version 3.0): an integrated software package for population genetics data analysis. Evol Bioinform Online 1:47-50

Gailing O, Vornam B, Leinemann L, Finkeldey R (2009) Genetic and genomic approaches to assess adaptive genetic variation in plants: forest trees as a model. Physiol Plant 137:509-519

Geßler A, Keitel C, Kreuzwieser J, Matyssek R, Seiler W, Rennenberg H (2007) Potential risks for European beech (Fagus sylvatica L.) in a changing climate. Trees-Struct Funct 21:1-11

Ingvarsson PK, Garcia MV, Luquez V, Hall D, Jansson S (2008) Nucleotide polymorphism and phenotypic associations within and around the phytochrome B2 locus in European aspen (Populus tremula, Salicaceae). Genetics 178:2217-2226

IPCC-Intergovernmental Panel on Climate Change (2007) Climate change 2007: the physical science basis, contribution of working group I to the fourth assessment report of the intergovernmental panel on climate change. In: Solomon S, Qin D, Manning M, Chen Z, Marquis M, Averyt KB, Tignor M, Miller HL (eds) Cambridge University Press, Cambridge

Peakall R, Smouse PE (2006) GENALEX 6: genetic analysis in excel. Population genetic software for teaching and research. Mol Ecol Notes 6:288-295

Rennenberg H, Seiler W, Matyssek R, Gessler A, Kreuzwieser J (2004) European beech (Fagus sylvatica L.) - a forest tree without future in the south of Central Europe? All Forst-u J-Ztg 175:210-224

Rousset F (2008) GENEPOP'007: a complete re-implementation of the GENEPOP software for Windows and Linux. Mol Ecol Res 8:103-106

Seifert S, Vornam B, Finkeldey R (2012) DNA sequence variation and development of SNP markers in beech (Fagus sylvatica L.). Eur J For Res. doi:10.1007/s10342-012-0630-9 